\title{
OFEATURE
}

\section{People Behaving Badly, or Can We Get an Adult in the Room?}

\section{James LaRue (jlarue@ala.org), Director, ALA Office for Intellectual Freedom and Executive Director of the Freedom to Read Foundation.}

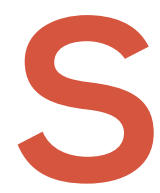

hut Up! (self-published 2016; ISBN 978-1-5333-8233-7) is a self-published book about a war between authors Megan Fox and Kevin DuJan and the Orland Park Public Library (OPPL) - except mostly, it isn't. That modest story really doesn't require 651 pages. On this topic, in the words attributed to Ambrose Bierce, "The covers of this book are too far apart."

What does fill the pages, then? There are many words of praise for people hailed as "great conservatives, writers, and pundits" such as Rush Limbaugh, Ann Coulter, and Andrew Breitbart (to whom the book is dedicated). On the other hand, the authors believe that even the people they describe as good, honest, unfailingly truth-seeking conservative talk radio hosts are just too timid to withstand the oppressive, unscrupulous importunities of the liberal left. Welcome, again, to the culture wars.

There's quite a bit about the tactics of Saul Alinsky, a 60s-era community organizer who wrote Rules for Radicals in 1971. DuJan both excoriates and emulates Alinsky, who attempted to effect change by sowing mischief, ridicule and mockery. In Alinsky's case the intent was to advocate for the poor in Chicago, and he was by many accounts very successful, and influential culturally. DuJan uses the same tactics - but mostly because he enjoys it so much.

Fox, meanwhile, has ambitions as a conservative commentator and writer-for Glenn Beck's The Blaze and WLS talk radio (p. 232). She talks about her visits to the Chicago Field Museum, and her utter disdain for the "silly" idea of evolution. During the course of the book, Fox has a third child, and there's a lot of writing about Fox and her kids roaming around Chicagoland, playing games, watching movies, and so on.

DuJan goes on at length in many places about another topic: the only good library is literally a poor one. By completely over-the-top contrast, OPPL is a "Taj Mahal." For instance, he describes the

sheer, unadulterated opulence of the soaring glass, sandstone, and sparkling steel structure that looked for all the world like the sort of modern mausoleum befitting the entombment of a sainted pope, a beloved American president, or a pop star of Michael Jackson's magnitude. The Orland Park 


\section{SHUT UP! _ FEATURE 0}

Public Library is actually so ostentatious and monumental in exterior scale and scope that it looks like the sort of Frank-Lloyd-Wright-just-married-Liberace-in-Vegas love letter to extravagance in which the self-styled 'King of Pop' should have probably been interred (if only he had never went [sic] umbrella-toting, baby-dangling, face-disfiguring, career-ruining INSANE in his final decades). (p. 21-22)

In fact, OPPL is a nice library. But it's not that nice. There are also many pages of railing against the American Library Association (ALA) and the employees of the Office for Intellectual Freedom (OIF). Full disclosure: I am an employee of the ALA and the current director of the Office for Intellectual Freedom, although a relatively new one (I assumed my position in January of 2016). Before then, for almost twenty-four years I was the director of a public library in Colorado, where we created one of the first websites in the state, installed internet computers for the public, ran completely open access to them until forced by state law to adopt software filters, and managed the library for many years after that. I have also been, between my director days and my work at ALA, an avid library user, and library consultant. So, although I have my own biases which I will strive to make clear, I do know something about the topics of public administration, public policy, and the management of public internet access.

But let's get back to Fox and DuJan. They alternate chapters, and both of them have chatty, lively, and snarky prose styles. In fact, the use of language is the real focus of the book: an appallingly frank exposé of the rhetoric of the alt-right. Fox and DuJan put a staggering amount of time and energy into their battle. What they don't do is offer anything like a coherent or consistent philosophy, and the results of their work are anything but clear.

What I'll try to do in this extended book review and essay is:

- provide the essential facts of the case

- call out what I believe to be the underlying issues

- deliver a response to Fox and DuJan's fundamental allegations, and

- suggest what it all means for libraries.

\section{How It All Began}

The story is relatively simple. One day in 2013 or 2014, suburban homeschooling mom Megan Fox, claims that she, her two kids (then aged four and seven), and her friend Kevin DuJan (whom she describes as "A conundrum. Gay. Conservative. Catholic. Republican" [p. 15-16]) went on an outing to the Orland Park Public Library. OPPL is an independent library district in the village of Orland Park, an Illinois suburb about twenty-six miles southwest of Chicago. The library serves a community of around 56,000 people. Although Fox and DuJan are a little cagey about where they do live, it appears that neither one of them is in fact a resident of Orland Park. But most Chicago area libraries extend borrowing privileges to each other's residents as a matter of courtesy.

Once at the library, Fox attempted to use a children's computer to gain access to the internet, and, she and $\mathrm{Du}$ Jan allege, a "shrieking" children's librarian warned her off. Local rules forbade adults unattended by children from using children's computers.

So Fox went upstairs to the OPPL computer area, which she and DuJan call the "Masturbation Lounge." She doesn't mean that she saw anyone engaged in physical acts of masturbation there. She just means that she saw people viewing "pornography." In fact, she writes (p. 36), on her very first walk-through just a few steps from the computer area,

I found exactly what I knew I would. All the authors that are the worst of the worst as far as porn, drug use, deviant behavior and sex were all displayed colorfully and innocently as if they contained stories about girls doing upstanding activities like becoming prima ballerinas or Chief Executive Officers or other contributing members of society and not detailed accounts of how to insert spermicidal foam into southern orifices and masturbate in a bathtub.

That's quite an accusation. But it's also a lot to have gathered from a glance and a walk-through.

What did she see? Apparently, she saw exactly what she knew she would, a report comprising more ginned-up outrage than credibility.

But let's be fair: later there were indeed police reports of one person who was alleged to have masturbated in front of a patron, and another (or the same person) who exposed himself. I don't doubt that this happened, by the way; libraries are public places. What I do doubt is that this criminal behavior is, as they allege, the fault of the library director, the Office for Intellectual Freedom, and the American Library Association. Surely the criminal bears some responsibility.

On the basis of this encounter, she and DuJan filed against OPPL not just a complaint of bad customer service, but Freedom of Information Act (FOIA) requests for everything to do with library computers. 


\section{SHUT UP! _ FEATURE}

So that's the core concern: patrons (not in the children's room, where internet access was limited to children, and was, moreover, filtered) were being "permitted" to view sexual images on the internet. Moreover, they were able to do so without using their library cards to login; rather, they had a pass that preserved their anonymity.

\section{Library Response}

The rest of the story then focuses on the responses of the library director and board to the FOIA requests and the original complaint. Generally, these fall into three areas.

\section{FOIA Responses}

Fox and DuJan make allegations that the library director stalled, colluded with others in the village and generally acted in bad faith: not providing things in a timely fashion, over-redacting records, and not providing them in the preferred electronic format. DuJan and Fox responded with even more FOIA requests, touching on communications between library staff and others, expenses on board lunches, conference travel, and even, eventually, personnel records. By and by, DuJan and Fox sued OPPL for failure to comply adequately to the sheer number of requests. The result of that challenge was reported under the significantly misleading Chicago Tribune headline "Orland Park Library to Pay $\$ 55 \mathrm{k}$ to Settle Lawsuits Related to Internet Porn." In fact, pornography was never addressed in the lawsuit or the settlement.

How many FOIA requests were there? "In September, library officials said they had received 133 open records submissions containing 742 distinct requests for documents since the dispute began, mostly from Fox, DuJan or others submitting requests with the same email address."

What did Fox and DuJan want to know? "Many requests sought information on library policies, personnel and spending, but one asked why a trustee wears a similar red outfit at each meeting, whether it was a form of 'hazing' or the library has 'anything in writing that explains why she dresses up as Mrs. Claus every month,' according to library documents."

The settlement didn't involve a finding of guilt, nor did OPPL admit fault for violating transparency laws. But the settlement did call out how such requests were to be handled in the future. Eventually, the library and village got familiar with the laws and processes of FOIA, and responded more fully and consistently. But the requests continued and continue still. By the end, DuJan filed FOIA requests with every public library in the state, and even tracked employees from OPPL to other libraries.

\section{Board Meetings}

At various board meetings, moreover, Fox and DuJan came to accuse and protest, filmed proceedings and encounters, and had various encounters during and after board meetings that can only be described as childishly confrontational, often on both sides. Judge John J. Tharp, Jr., in dismissing another lawsuit, described one postBoard meeting scene as follows: "The entire incident lasted less than 90 seconds and could have been avoided entirely if either side had behaved maturely and gone about their business rather than provoking the opposing group. Instead, several of the antagonists . . engaged in almost three years of litigation before settling their dispute."

\section{Changes in Policy and Practice}

One of the goals of Fox and DuJan was to get the OPPL to stop "permitting" patrons to view pornography. Although the book never detailed any kind of comprehensive strategy or recommendations to achieve that, the following actions were at least suggested: getting staff to call the police whenever anybody looked at "porn," the installation of software filters on all public terminals, and a much tighter scrutiny of public behavior. However, the OPPL board did not, in fact, adopt filtering or change their policies. Some internet workstations in the adult area were moved to be more visible to the staff.

That's a lot of bother for, in the end, not much change.

\section{Pornography}

One of the persistent and frustrating omissions in the book is the repeated use of a term the authors never define. That term is "porn." Let's take a moment to review the law.

The authors repeat several times that the Supreme Court has stated that there is no right to access pornography, particularly in the library. But the truth is much simpler: there is no legal definition of pornography at all. Pornography just means "appealing to an interest in sex." If judged only by American advertising, pornography is ubiquitous.

The law, set out by the Children's Internet Protection Act (CIPA) and interpreted by the US Supreme Court, is pretty specific about what kind of sexual imagery (and regarding library computers, it only addresses images) is illegal. In order of clarity, illegal imagery falls into three categories:

- child pornography,

- obscenity, and

- harmful to minors. 


\section{SHUT UP! _ FEATURE}

Since CIPA, school and public libraries must adopt an internet use policy for adults and minors, and use a "technology protection measure" (software filters) in four broad cases, mainly when they accept certain kinds of federal money.

There are many libraries in Illinois that don't have to filter, and choose not to. Some do, or, as with OPPL, filter children's computers only. OPPL is not unique. Nor is there any reason to believe, besides Fox and DuJan's sayso, that people behaved worse at OPPL than elsewhere (the nearest shopping mall, for instance), or that local policies were the cause.

But note that in the same court case that the authors repeatedly cite (United States v. American Library Association, Inc., 2003) the Supreme Court has also stated clearly that if internet filters are in use, adults have the right to direct that they should be turned off for things blocked by the filter, but not falling into the above categories. ${ }^{3}$

To summarize: according to the highest court in the land, pornography by itself isn't illegal, but some kinds are. If libraries do use a filter, adults have the right to demand an immediate disabling of it, and expect librarians to comply.

That's a messy situation. Fox and DuJan blame librarians for all of it.

Now let's take a closer look at the specific categories of illegal sexual imagery.

\section{Child Pornography}

Child pornography involves the depiction of real minors (under the age of 18) committing sexual acts. It is a crime, and a heinous act. Fox is indignant that some librarians don't have the instant ability to judge child pornography. What's the problem? It's "porn . . involving children," she writes. Is there something not totally clear here?

Suppose librarians walk past a computer screen where someone is viewing the rape of a child obviously in, for instance, elementary school. Should they call the police? Yes. They should. They have.

But suppose librarians walk past a patron streaming the scene in the movie "Juno" where the title character gets pregnant. Ellen Page, to my eye, looks about twelve in that scene. In fact, she was twenty. "Juno" was rated PG13. Is it pornography when a film shows (generally) two apparent teenagers (her costar, Michael Cera, was twenty-one at the time) having sex? If a fourteen-year-old is watching it at the library is it a sex crime? I think Fox and DuJan would say it was. But it isn't.

Or suppose someone views a manga animated short that shows a naked family bathing together. It's artwork, which means that no children were actually involved. And in Japan, family bathing is a cultural norm. Is it child pornography? Some have said so. The accusation itself is deeply offensive to people raised in that tradition. It, too, is false.

As is so often the case, snap judgments can be wildly wrong and irrelevant.

\section{Obscenity}

Fox and DuJan believe that librarians willfully withhold (for reasons I will get to below under "What's wrong with librarians?") their judgment to declare something obscene. The authors are incensed by OIF's statement that "librarians are not judges."

In Miller v. California, the Supreme Court declared three tests to find obscenity. ${ }^{4}$ (A good overview can be found here.) Interestingly, not all $\mathrm{Su}-$ preme Court justices agreed. In the highest court in the land, among the finest legal minds, there were dissenting opinions.

It seems that Megan Fox, in her mind an average person in firm grasp of community standards (although not her community), could stroll through a computer center and reach this complex conclusion in seconds. But the $\mathrm{Su}-$ preme Court couldn't, or not unanimously.

If they can't, how can librarians? That's what's behind the OIF's historic statements. Obscenity is a finding of the courts. And in a world after the success of Fifty Shades of Grey, it's not at all predictable.

To sumarize: the Miller test is almost impossible for the library to administer. On one extreme or the other things may seem clear, but life is lived in the very muddled middle. Administration of public internet use has its challenges.

\section{Harmful to Minors}

"Harmful to minors" is even less coherent as a standard. That is, things that might be OK for adults might not be ok for minors. And how old is the minor, exactly? Up to four years old? Then they're not typing searches into the internet. Are they five to twelve? Then we get to another class 


\section{SHUT UP! _ FEATURE}

of minor, aged thirteen to seventeen years. At that age spread, "minors" are keenly interested in human behavior of people older than they are. Is the "child" of seven truly the same as one of seventeen, when just one year later, he or she will be able to marry, to go to war, and to vote? Of course not. All minors are not equal.

And lest we forget, even minors, of all ages, do have First Amendment rights, as have been repeatedly upheld by the courts. Among these is the right to receive information, even when school officials, for instance, don't like the topic or approach. ${ }^{5}$

It is certainly the case that the internet exposed a lot of previously hidden sexual content in our culture, not just in libraries, but also through now-common smartphones. That's a technological and social shift. Libraries didn't precipitate that. But they are one of the many places where people go to access internet connections-often because sometimes people have no other option. I get that society in general isn't immediately comfortable with the changes. Neither are all librarians. But blaming librarians for a failure to thoroughly manage the internet and human libido is like blaming firefighters for a volcano.

\section{Filtering}

So the internet offers access to illegal imagery. Fox and DuJan seem to think filtering - the technology protection measure called for by CIPA- just solves the problem. But ALA's historic opposition to filtering is based on two key facts:

- No filter completely blocks the three categories of child pornography, obscenity and harmful to minors. Something always gets through.

- All filters on occasion over-block (identifying something as illegal that isn't). At the OIF we hear many reports of school libraries, in particular, whose filtering is so aggressive that it blocks electronic news sources the library pays to receive. To be fair, often this is the result not so much of the filter as the ham-handed implementation of it by people who aren't librarians. IT staff flip every switch the software offers, blocking "hate speech," alternative life style choices, drug use, and so on. In the process, they frequently violate the Constitutional rights of students.

There are other worries. Chief among them is a lack of transparency. Filtering is provided by companies that block content using proprietary algorithms. That is, a government agency charged with providing information (the library) has no way to know just what is being blocked, or how, or why. Unless and until libraries come up with their own filtering software-and software development isn't a traditional library skill—filtering software will be suspect. Librarians' suspicion of filters is a good thing, bespeaking an unwillingness to give up the liberty of inquiry for the illusion of safety.

On the other hand, as a library director I had no objections at all to using even "whitelist" filtering in the children's room. (The continuum is "live filtering," which interrupts even supposedly secure connections to scan for key words; then the less restrictive blacklist, or a frequently updated list of URLs that will not be displayed; then the most restrictive whitelist, which means one can only go to those sites.) I see nothing wrong with building a list of high quality, vetted sites, and only those sites, in an area designed for elementary school kids. It is certainly the case that not all internet imagery is appropriate for kids.

In other areas of the library, however, people use the internet for many perfectly appropriate and Constitutionally protected sources. Librarians need only step in when there's a problem. And of course, no matter where you are, there will be problems.

\section{Practice}

As I mentioned above, I have run public internet access both before and after the imposition of filtering. The truth is, it wasn't much different. In both cases, most people behaved well, and some people behaved badly. Although confronting misbehaving patrons can indeed be awkward, few librarians simply throw up their hands and say, "anything goes!"

Instead, most libraries do at least three things whether they filter or not:

- Supervise public space. We monitor the building, which is a combination of direct, line-of-sight review, and wandering around in the course of business.

- Investigate complaints. When a patron complains about something, staff goes over to take a look. Incidentally, not all complaints are accurate. I've investigated a "porn" complaint about somebody viewing a medical site about vasectomies. People have called "obscenity" what turned out to be women's Olympic volleyball games. An allegation of someone viewing "bestiality" was in fact a Youtube sheep-shearing demonstration. That said, sometimes people are indeed watching explicit sexual activity, and even very extreme examples.

- Take what seems to be appropriate action. There are times when the viewing of adult sexual activity is disruptive or rude. In such cases, it isn't uncommon for librarians to tell the patron to desist, or be thrown out 


\section{SHUT UPI _ FEATURE $₫$}

of the library. I'm not sure if such a circumstance would stand up to Supreme Court scrutiny or not. Neither is anybody else.

\section{The Smoking Gun}

Now that we have some context of the law and practice of public internet access, let's take another look at OPPL. Did they have a problem? That is, had what Fox and DuJan called "creeps" taken over the library for the non-stop viewing of illegal content?

Based just on the evidence Fox and DuJan present, I think the answer is: Maybe. Sometimes. As I noted above, every library has people who test the limits. Some get away with it. Some get caught. And sometimes a lax environment acts as a magnet for the ill-behaved. But a few random reports over the space of years are hardly proof of a publicly funded peepshow. Fox and DuJan's whole incendiary style is based on deliberate distortion. It's an Alinsky tactic. The authors assert as fact things that are only speculation, and often wrong.

The "smoking gun" at the center of Fox and DuJan's diatribe against OPPL is a claim of the actual viewing of child pornography at the library. The redacted police report is on page 164. A female patron reported to the reference desk that another patron, male, was viewing child pornography.

But the reporting patron refused to leave her name. The staff member reported the incident to IT staff, who upon investigation, saw nothing but Medicare sites. When the patron returned a few days later, the director confronted the patron with the reported behavior. The patron then admitted that something "inappropriate" had shown up on his screen, but it wasn't his fault. That certainly sounds fishy.

According to Fox and DuJan, the staff should have immediately summoned the police upon the first report. But there was no proof of child pornography. There was only an allegation. If the police had indeed been summoned and had indeed shown up, there was no identifiable witness (she explicitly asked not to be identified) and despite their investigation (by both IT staff and director) staff had no direct knowledge of misbehavior (he was seen by them to be looking at medical sites). If the patron had indeed been viewing child pornography, there wouldn't be enough information to arrest anyone, although it might scare the person away. If he were in fact guilty, that would not be a bad thing. On the other hand, if the original complaint were in fact mistaken, staff would then have publicly embarrassed someone who was entirely innocent, and now furious.
Is the problem of people misbehaving by seeking sexy content at OPPL worse than other libraries in the country? Probably not greatly so. But if it were, would that be ALA's fault?

This is where it gets hard to take Fox and DuJan seriously. If someone exposes himself at the mall, do you blame the businesses? If someone robs a store, do you blame the store? Fox and DuJan don't just allege that lax enforcement of public internet use allows people to get away with more than they would otherwise. They claim that libraries actively encourage and promote child pornography - an accusation without evidence anywhere in policy or procedure. Fox and DuJan seem to believe that libraries could and in Oklahoma, they claim, do stamp out the viewing of pornography altogether. In Illinois, it seems, it's only the ALA that stops them. That just doesn't seem very likely.

\section{Calling the Police}

But Fox and DuJan often contradict themselves. On the one hand, they have no patience for the failure of librarians to call the police. In fact, Fox in particular believes that no one in a public space, or anywhere online, should have any expectation of privacy (p. 34). The only people who want confidential internet service she says, are "criminals and the ALA" (never mind folks who are doing electronic banking, international business, or are trying to steer clear of estranged ex-husbands).

Yet DuJan doesn't have much good to say about police, whether in Orland Park or greater Chicago. Fox (p. 528) found them completely unresponsive when she reported death threats against her and her children. I believe that she got those threats, by the way. As we know from recent cases (Leslie Jones's Twitter harassment, for instance), such frightening and uncivil displays are all too common, a part of the coarsening of our public lives.

Trust the police? Don't trust the police? Call them but don't expect results?

\section{What's Wrong with Librarians?}

Another internal contradiction is Fox and DuJan's insistence that they love libraries, but completely dismiss the values of librarianship. Fox on page 208: "The Freedom to Read Statement, and the Library Bill of Rights often contradict local ordinances against lewd behavior and indecent exposure in public. All of it is a bunch of hooey. . . A A bunch of tattooed social justice warrior librarians sitting around making up policies while comparing eyebrow piercings does not a Constitutional Convention make." 


\section{ShUt UP. _ feature}

\section{THE LIBRARIANS [IN 1985] WERE HORRID, AS LIBRARIANS USUALLY WERE BACK THEN [AND SHOULD BE].}

The problem, DuJan writes (p. 483) is that "people all the time are heard to say, I haven't thought about the library in years. I forget it was even still there. Who goes there anymore? The library has become the place for creeps to hang out and watch porn. Why are tax dollars paying for that?"

Of course, the Library Bill of Rights does not contradict local ordinances-unless they contradict the First Amendment. And people are not "all the time" heard to say what DuJan imputes to them. This is just more altright rhetoric, invented from whole cloth.

DuJan concludes: "To stay relevant and 'exciting,' the ALA seems to have arbitrarily decided that sex needs to be pushed hard nonstop in libraries whether communities like or want that or not."

Further, DuJan says (p. 485) "the idiots who work at the ALA ... are the dumbest people on the face of the planet." In fact, regarding ALA and the OIF, he wonders if "perhaps these people are all evil, sick, serial child abusers who enjoy harming and sexualizing children and actively creating dangers for kids in public libraries with their warped policies."

DuJan isn't sure we need library buildings or librarians at all. He says (p. 482) that "while a fancy library is nice to have in a town ... a village would save a fortune by setting up downloadable eLibraries."

So we may conclude that Fox and DuJan don't approve of today's standards of librarianship as promulgated by ALA. What should librarians be doing instead? Fox on page 603: a librarian should be "someone who protects kids, keeps order, is stern when she needs to be, and doesn't let the strife intrude into the quiet of the library."

On the cover of Shut Up! is an unpleasant stereotype of a librarian with the bun, the glasses, the sweater, the pursed lips, the finger to mouth. (She's holding a copy of Alinsky's Rules for Radicals.) But the surprise is that this is how both authors think librarians should be, a return to the golden era. Fox reckons that would be 1985, pre-internet, when "it was all good"(p. 71). Earlier (p.
68), Fox discussed her childhood use of the Palos Hill library where "the librarians were horrid, as librarians usually were back then (and should be) and would brook no disobedience of their rules."

But remember that when Fox encountered just such a librarian who tried to sweep an adult from internet terminals in the children's area, Fox filed a complaint against her. What they say they want was exactly the thing that got this whole ball rolling.

\section{Substantive and Respectful Public Discourse}

I'm going to suggest that there's another problem, larger and more serious than a concern about the use of public computers to view sexual imagery. It's not Fox and DuJan. It's not ALA. It's the loss of civil and civic discourse, and the barely concealed attempt to unravel public institutions.

To quote again from Judge John J. Tharp, Jr.,

"From the information already at issue in this case. . . the behavior of some of the partisans in both camps bears little resemblance to the sort of substantive and respectful public discourse that should ideally characterize debates about important public policy issues and instead exemplifies the sort of juvenile tactics one would expect to see the antagonists in a schoolyard playground argument employ." ${ }^{\prime}$

So let's scroll back to the beginning. Members of the public come to the library and see something they think is out of line: in this case, the viewing of graphic sexual imagery.

Let's lay out the ground rules:

- Everyone should try to follow the law, both people charged with running the library and the people using them. (Note that sometimes the laws are themselves a little unclear or self-contradictory.)

- It's reasonable for the public to make a complaint when they think it's justified.

- Some complaints are justified, if not all of them. Complaints should be promptly investigated.

- Regarding the use of public internet terminals, all libraries should have a clear statement of appropriate use. They should also have a policy about appropriate patron behavior. (OPPL had both.)

- If they have to, or choose to, take federal erate money, libraries should filter, but only for graphic sexual imagery, and only with software that can be turned off, as the Supreme Court has said. 
- Whether they filter or not, librarians have the obligation to oversee public space.

- Anonymous library use and the destruction of internet use records is a best-practice way to preserve individual privacy. Some criminals will benefit. But so will the majority of law-abiding library users. (And for those altright readers: apply the same logic to gun registration.)

- Libraries should be open and transparent according to the law. That means open meetings, responsiveness to citizen comments and concerns, and timely response to FOIA requests. FOIA can be used to excess, and even abusively. At that point, we can't expect public institutions to be both transparent and efficient.

- Library officials and staff should be courteous and welcoming.

- Decisions about policy and practice should be based on thoughtful and mature consideration of the law, the facts, and both the library and community values.

Most of these things are a matter of law. But notice that these are the responsibilities of gov-

ernment. What are the obligations of the citizen?

Is it too much to ask that people should begin with courtesy and charity? Fox and DuJan would no doubt say that they don't have to and nobody can make them. That's true, too. But it's the argument of a twoyear-old. "America is one of the only places on Earth where ridiculing and publicly condemning public officials is not 'defamation," claims a jubilant DuJan (p. 481).

I don't want to excuse the times when OPPL board and staff may also have been less than courteous or forthcoming. As I say, library officials and staff should be welcoming and polite. They need to follow the law. But it's also clear that Fox and DuJan opened a dialog with the library that began with accusations and demands. After that, well, DuJan's avowed intent to say whatever gets a rise out of the government makes him an utterly unreliable reporter.

Moreover, I can't help but think the sheer, litigious drama of the years-long battle was high in emotion and low on results. Fox and DuJan did their all-out best to damage the reputation of the library not just by exaggerating the level and frequency of patron misbehavior, but by digging up and fanning nasty interpretations of older library issues, launching attacks against library staff members on social media, and ignoring the profoundly good work OPPL does in the promotion of child literacy through programs and storytimes. That kind of collateral damage had nothing to do with their original complaint. They end by accusing librarians of being sex criminals.

To what end? To establish a sharper definition of pornography? To force a library of a community in which they did not reside to adopt broad internet filtering? To change the policies of the library? They didn't accomplish any of those things. Their achievement, finally, seems entirely corrosive.

Many librarians these days are working on civic engagement, on the attempt to foster meaningful conversation among citizens about issues that matter. Attack and defend is one kind of dialog, and it's very much the realm of today's politics. But like Judge Tharp, I think that serious matters might deserve a little dignity and mutual respect, a little more listening on both sides.

Is it reasonable to want to have a public discussion about the appropriate uses of public computers? It is. Is it reasonable to wonder about the use of FOIA to move from a legitimate interest in government transparency to the politics of personal destruction? Yes.

When discourse devolves to name calling, willful distortion, and the assumption of evil, we have gone too far. We're no longer listening to each other, and we're no longer acting like responsible citizens. We are behaving badly. Sometimes we need an adult in the room.

\section{Should You Buy This Book?}

For several months, Shut Up! has been marketed via social media to a variety of lists populated precisely by the people the book attacks. It's a curious strategy: send spam (unwanted solicitations of commercial transactions) to people your product calls idiots and criminals. But the marketing does something clever: it alleges censorship of this book by ALA. Are you obliged to buy this book or face the charge? 


\section{PEOPLE BEHAVING BADLY _ FEATURE}

According to Fox and DuJan, the answer is no. "No books are really 'banned' in America today!” (p. 427).

\begin{abstract}
The only time censorship exists is when a government body silences the thoughts or opinions of certain people, doesn't let them speak, doesn't allow a book to be published, threatens people with arrest or other punishment because of their unpopular opinions, removes content from the internet, files a lawsuit to chill First Amendment protected speech, etc. No library has the power to "censor" any book or prevent it from existing.
\end{abstract}

Ergo, if you don't buy the book, you're not censoring it. Take it from the experts.

But that isn't the definition of censorship as used by ALA. Rather, we talk about the deliberate suppression of information. That's something worth keeping our eye on.

Is the book a good buy for your library?
Shut Up! falls well within the rhetorical genre of Limbaugh, Coulter, and other right-wing media darlings, meaning that it's long on accusation, and even longer on absurd conclusions. If your community has an appetite for that, it will probably enjoy this, too, despite its meandering and often tedious length. University libraries tracking the rise and fall of that movement may find it a representative period piece. If you work for a library school studying the perceptions and challenges of the public library, and the adoption of the internet in American society, it's a relevant case study. If you're in the vicinity of Chicago and Fox and DuJan's friends (if they have any residing in your community) are clamoring for the book, it won't kill you to buy a copy, if your distributor carries it. But whether you do or don't, it's of little consequence. Ultimately, Shut Up! is a terrific example of people behaving badly. Not that we need more of them.

\section{Notes}

1. Lauren Zumbach, "Orland Park Library to Pay $\$ 55 \mathrm{~K}$ to Settle Lawsuits Related to Internet Porn," Chicago Tribune, March 19, 2015, www.chicagotribune.com/suburbs/daily-south town/news/ct-sta-orland-library-settle-st-0320-20150319 -story.html.

2. Order, Bittman v. Fox, No. 14C 08191 (N.D. Ill. May 16, 2016), https://casetext.com/case/bittman-v-fox-2.
3. United States v. American Library Association, Inc., 539 U.S. 194 (2003).

4. Miller v. California, 413 U.S. 15 (1973).

5. See Counts v. Cedarville School District, 295 F. Supp. 2d 996 (W.D. Ark. 2003).

6. Order, Bittman v. Fox.

\section{Subscribe to the Journal of Intellectual Freedom and Privacy}

Subscribe to the only quarterly journal dedicated to both professional discourse and current news about intellectual freedom and privacy issues in libraries. Subscriptions include access to the archives for the Journal of Intellectual Freedom and Privacy.

The annual cost for the Journal of Intellectual Freedom and Privacy is $\$ 50.00$ per year for four issues. To subscribe by mail, send payment and information to Subscription Department, American Library Association, and 50 East Huron Street, Chicago, IL, 6061l. Subscriptions may also be submitted online at www .ala.org//cfapps/subscriptions.

For multiple subscriptions to the same address, subscription inquiries, and for back issues, please contact the Office for Intellectual Freedom at 800-545-2433, x4223 or oif@ala.org. 